\title{
Further studies on prostaglandin and thromboxane production by the rat uterus during the oestrous cycle*
}

\author{
Carol G. Brown† and N. L. Poyser
}

Department of Pharmacology, University of Edinburgh, 1 George Square, Edinburgh EH8 9JZ, U.K.

\begin{abstract}
Summary. Prostaglandin (PG) and thromboxane (TX) synthesis by uterine homogenates was measured at 4- $h$ intervals during the 4-day oestrous cycle of rats. Production was in the order of 6-oxo-PGF-1 $\alpha$ (which reflects PGI-2 synthesis) $>$ PGF- $2 \alpha>$ TXB2 (which reflects TXA-2 synthesis) $\geqq$ PGE-2. Peak production occurred at $02: 00 \mathrm{~h}$ on the day of oestrus, after which production gradually decreased, with some fluctuation on the day of metoestrus, to reach a minimum between $22: 00$ and $06: 00 \mathrm{~h}$ on the days of dioestrus and oestrus, respectively. Separation of the uterine tissues showed that, on a unit weight basis, the endometrium had a much higher PG and TX synthesizing ability than did the myometrium, although this was compensated for on a total weight basis by the much greater mass of myometrium. Endometrial PG and TX production was in the order of PGF- $2 \alpha>$ TXB-2 $\geqq 6$-oxo-PGD- $1 \alpha \equiv$ PGE-2, with PGF- $2 \alpha$ and TXB-2 productions showing the greatest increases between 10:00 and 02:00 h on the days of pro-oestrus and oestrus, respectively. Myometrial PG and TX production was in the order of 6-oxo-PGF-1 $\alpha>$ PGF- $2 \alpha>$ PGE-2 $\equiv$ TXB-2, with 6-oxo-PGF-1 $\alpha$ and PGF- $2 \alpha$ productions showing small increases between 10:00 and $02: 00 \mathrm{~h}$ on the days of pro-oestrus and oestrus, respectively. Myometrial PGE-2 production decreased between these two times. Progesterone and oestradiol treatment significantly $(P<0.05)$ increased PGF- $2 \alpha$ and TXB-2 synthesis, but not 6-oxo-PGF-1 $\alpha$ and PGE-2 synthesis, by uterine homogenates from long-term ovariectomized rats but not from acutely ovariectomized rats. Since the uterine tissue concentrations of PGF-2 $\alpha$, TXB-2 and 6-oxo-PGF-1 $\alpha$, but not of PGE-2, were significantly $(P<0.05)$ higher at $02: 00 \mathrm{~h}$ on the day of oestrus than at 10:00 h on the day of pro-oestrus, increased uterine PG and TX production may be involved in increasing sperm transport through the uterus at the time of ovulation (i.e. around $02: 00 \mathrm{~h}$ on the day of oestrus) by stimulating uterine motility.
\end{abstract}

\section{Introduction}

During the rat oestrous cycle, prostaglandin (PG) concentrations in the uterus (Ham, Cirillo, Zanetti \& Kuehl, 1975; Van Orden, Goodale, Baker, Farley \& Bhatnagar, 1980) and PG-synthesizing ability of the uterus (Thaler-Dao, Saintot, Ramonatxo, Chavis \& Crastes de Paulet, 1982a) have been reported to be highest on the day of pro-oestrus. However, Ham et al. (1975) and Poyser \& Scott (1980) report that uterine PG-synthesizing ability is highest on the day of oestrus. PG output from the rat uterus in vitro is also highest on the day of oestrus (Ishikawa \& Fuchs, 1978), while PGF-2 $\alpha$ output from the uterus in vivo during the oestrous cycle shows three peaks at 14:00-16:00

\footnotetext{
* Reprint requests to Dr N. L. Poyser.

+ Present address: Department of Biochemical Endocrinology, Chelsea Hospital for Women, Dovehouse Street,
} London SW3 6LT, U.K. 
$\mathrm{h}, 02: 00-04: 00 \mathrm{~h}$ and 10:00-12:00 $\mathrm{h}$ on the days of pro-oestrus, oestrus and metoestrus, respectively (Saksena, Shaikh \& Shaikh, 1973). It is apparent that PG production by the rat uterus changes during the cycle, but it is not clear when precisely maximum production occurs because measurements have been made only once or twice daily during the cycle. We have therefore measured the PG and thromboxane (TX) synthesizing ability of the rat uterus at 4-h intervals during the 4-day oestrous cycle. Further experiments were then performed to explain our findings.

\section{Materials and Methods}

Wistar rats weighing 200-250 g were housed in controlled lighting conditions (lights on 06:00$20: 00 \mathrm{~h}$ ). Vaginal smears were taken daily and examined microscopically. Oestrus was taken as the day of maximum cornification preceding the day of leucocyte infiltration. All rats had shown at least two regular 4-day cycles before being used in the experiments. Rats used in Exps 1-4 and Exp. 6 also provided ovarian and/or hypothalamic tissue for other studies (Brown \& Poyser, 1984a, b).

Experiment 1 . Six rats were killed at $02: 00,06: 00,10: 00,14: 00,18: 00$ and $22: 00 \mathrm{~h}$ on each day of the 4-day cycle (total of 144 rats). The uterus from each rat was removed, weighed, and then homogenized in $15 \mathrm{ml}$ Krebs' solution (for composition, see Mitchell, Poyser \& Wilson, 1977). Each uterine homogenate was incubated at $37^{\circ} \mathrm{C}$ for $90 \mathrm{~min}$ and aerated with $95 \% \mathrm{O}_{2}, 5 \% \mathrm{CO}_{2}$. After incubation, the $\mathrm{pH}$ of each incubate was adjusted to 4.0 with $\mathrm{NHCl}$, and the lipids were extracted by shaking twice with 2 volumes of ethyl acetate. The two ethyl acetate fractions were combined and evaporated to dryness at $45^{\circ} \mathrm{C}$ on a rotary evaporator. Each dried extract was redissolved in $10 \mathrm{ml}$ ethyl acetate, and stored at $-20^{\circ} \mathrm{C}$ until the amounts of PGF- $2 \alpha$, PGE-2, 6-oxo-PGF- $1 \alpha$ and TXB2 present were measured by radioimmunoassay (RIA). Recovery is high ( $>80 \%$ ) by the extraction method (Poyser \& Scott, 1980; Swan \& Poyser, 1983), and the results were therefore not corrected for procedural losses. After being assayed, the uterine samples were pooled, purified further by silicic acid column chromatography and analysed by gas chromatography-mass spectrometry, as described by Poyser (1983).

Experiment 2. Six rats ( 3 at each time) were killed at 10:00 h on the day of pro-oestrus and $02: 00$ $\mathrm{h}$ on the day of oestrus. The uterus from each rat was removed, weighed and homogenized in $15 \mathrm{ml}$ ethanol. Each homogenate was centrifuged at $1000 \mathrm{~g}$ for $15 \mathrm{~min}$, and the supernatant liquid was withdrawn and evaporated to dryness. Each extract was dissolved in $10 \mathrm{ml}$ water, and the PGs and TX were extracted, stored and measured as in Exp. 1.

Experiment 3. Uteri from 4 rats, killed at $10: 00 \mathrm{~h}$ on the day of pro-oestrus, were removed, weighed, incubated and extracted, and the PGs and TX were measured as in Exp. 1, except that arachidonic acid ( $2 \mu \mathrm{g} / \mathrm{ml}$; Sigma Chemical Co. Ltd., Poole, U.K.; $99 \%$ pure) was added to each homogenate before incubation.

Experiment 4. Eight rats (4 at each time) were killed at 10:00 h on the day of pro-oestrus and $02: 00 \mathrm{~h}$ on the day of oestrus. The two uterine horns from each rat were separated, weighed, and homogenized in $10 \mathrm{ml}$ Krebs' solution, and $0.5 \mu \mathrm{Ci}\left[{ }^{3} \mathrm{H}\right] \mathrm{PGF}-2 \alpha$ (sp. act. $160 \mathrm{Ci} / \mathrm{mmol}$; Amersham International plc, U.K.) was added to each homogenate. In addition, nicotinamide-adenine dinucleotide (NAD $\left.{ }^{+} ; 2 \mathrm{mM}\right)$ and PGF- $2 \alpha(2 \mu \mathrm{g} / \mathrm{ml})$ were added to one of the uterine homogenates from each rat. Each homogenate was incubated and the lipids were extracted as in Exp. 1. This study was repeated with a further 8 rats except that $0.5 \mu \mathrm{Ci}\left[{ }^{3} \mathrm{H}\right] \mathrm{PGE}-2$ (sp. act. $160 \mathrm{Ci} / \mathrm{mmol}$; Amersham) and PGE-2 $(2 \mu \mathrm{g} / \mathrm{ml})$ were substituted for $\left[{ }^{3} \mathrm{H}\right] \mathrm{PGF}-2 \alpha$ and PGF- $2 \alpha$, respectively.

All the extracts were analysed by thin-layer chromatography (t.l.c.) using pre-coated silica gel t.l.c. plates (Merck, Darmstadt, West Germany) and a solvent system of chloroform, methanol, gla- 
cial acetic acid and water in the ratio of $90: 9: 1: 0.65$ (by vol.). Standard t.l.c. plates onto which had been spotted $10 \mu \mathrm{g}$ each of PGE-2, PGF-2 $\alpha$, 15-keto-PGE-2, 15-keto-PGF-2 $\alpha, 13,14$-dihydro-15keto-PGE-2, and 13,14-dihydro-15-keto-PGF-2 $\alpha$ were analysed similarly. Substances on the standard plates were visualized by exposure to iodine vapour for $30 \mathrm{~min}$. The silica gel was scraped off the radioactive plates at $0.5 \mathrm{~cm}$ intervals into scintillation vials. After adding $0.5 \mathrm{ml}$ methanol, $10 \mathrm{ml}$ scintillation fluid (10.5 $\mathrm{g}$ 2,5-diphenyloxazole in 2.51 toluene) were dispensed into each vial and the amount of radioactivity present was measured. The $R_{F}$ values of the radioactive compounds were compared with the $R_{\mathrm{F}}$ values of the standard PGs and PG metabolites. The amount of radioactivity associated with a PG metabolite was corrected for the loss of a tritium from the carbon at position 15. PG metabolism, at the two times studied, was calculated by expressing the amount of radioactivity associated with the PG metabolites as a percentage of the total radioactivity on the t.l.c. plate.

Experiment 5. The uteri from 6 rats killed at $10: 00 \mathrm{~h}$ on the day of pro-oestrus and 7 rats killed at $02: 00 \mathrm{~h}$ on the day of oestrus were removed, weighed and opened longitudinally. The endometrium was separated from the myometrium by scraping with a microscope slide, a technique which produces efficient separation of the two tissue types (Downing \& Williams, 1980). The myometrium was weighed, and the weight of the endometrium was calculated by difference. The two tissues were homogenized separately in Krebs' solution ( 2 and $15 \mathrm{ml}$ for the endometrium and myometrium, respectively). Each homogenate was incubated, and the PGs and TX were extracted, stored and assayed as in Exp. 1.

Experiment 6. Twelve rats (Group 1) were ovariectomized between $09: 00$ and 10:00 h on the day of dioestrus, under anaesthesia with alphaxalone and alphadolone $(5 \mathrm{ml} / \mathrm{kg}$ body weight; Althesin: Glaxo, Ware, U.K.). At $12: 00 \mathrm{~h}$ on that day, 6 rats received $10 \mu \mathrm{g}$ oestradiol benzoate in $0.5 \mathrm{ml}$ arachis oil subcutaneously (s.c.), and on the following day (the expected day of pro-oestrus) the rats were injected s.c. with $2 \mathrm{mg}$ progesterone in $0.5 \mathrm{ml}$ arachis oil. The 6 control rats received 0.5 $\mathrm{ml}$ arachis oil at both times.

Twenty-two rats (Group 2) were similarly ovariectomized under Althesin anaesthesia. After 6 weeks, 11 rats were injected s.c. with $10 \mu \mathrm{g}$ oestradiol benzoate in $0.5 \mathrm{ml}$ arachis oil, followed by 2 $\mathrm{mg}$ progesterone in $0.5 \mathrm{ml}$ arachis oil s.c. $72 \mathrm{~h}$ later. The 11 control rats were injected with $0.5 \mathrm{ml}$ arachis oil at both times.

The rats in both groups were killed $5 \mathrm{~h}$ after the progesterone injection (i.e. at $17: 00 \mathrm{~h}$ ). The uteri were removed, weighed, homogenized and incubated, and the PGs and TX were extracted, stored and measured as in Exp. 1.

Details of radioimmunoassays. PGF- $2 \alpha$, PGE-2, 6-oxo-PGF- $1 \alpha$ and TXB- 2 were measured using antisera raised in rabbits in this department, and their cross-reactivities have been reported elsewhere (Dighe, Emslie, Henderson, Rutherford \& Simon, 1975; Poyser, 1980; Poyser \& Scott, 1980; Lytton \& Poyser, 1982; Poyser, 1983). The only significant cross-reactivities are PGE-1 (94\%), PGB-2 (72.7\%) and PGA-2 (13.6\%) with the PGE-2 antiserum, and PGF- $1 \propto(100 \%)$ with the PGF$2 \alpha$ antiserum. The intra-assay coefficients of variation, calculated from the variation between the duplicate results obtained, were 9.2\% (PGE-2), 8.6\% (PGF-2 $\alpha$ ), 8.2\% (6-oxo-PGF- $1 \alpha$ ) and 8.0\% (TXB-2). The inter-assay coefficients of variation, calculated from the results obtained by incorporating a known amount of the appropriate compound into each assay, were $12.6 \%$ (PGE-2), $11 \cdot 1 \%$ (PGF-2 $\alpha$ ), 9.7\% (6-oxo-PGF-1 $\alpha$ ) and 6.1\%(TXB-2). The detection limit per assay tube was 40 pg PGE-2, 40 pg PGF-2 $\alpha, 40$ pg 6-oxo-PGF-1 $\alpha$, and 30 pg TXB-2.

Statistical tests. In Exp. 1, the results were analysed by Duncan's multiple range test. In the other experiments, appropriate comparisons were made using Student's $t$ test. However, if the variances were unequal by the variance ratio $F$ test, then a modified $t$ test for unequal variances was used. 


\section{Results}

\section{Experiment 1}

Analysis by GC-MS showed that PGE-2, PGF-2 $\alpha, 6$-oxo-PGF-1 $\alpha$, TXB-2 and PGD-2 were present in the extracts of incubated, rat uterine homogenates. PGA-2, PGB-2, PGE-1 and PGF-1 $\alpha$ were not detected (detection limit 25-100 ng total, depending upon the PG). Consequently, the PGE-2 and PGF- $2 \alpha$ antisera were measuring predominantly the PG to which they had been raised.

The major PG produced by whole uterine homogenates was PGI-2 (measured as 6-oxo-PGF$1 \alpha$ ) followed by PGF-2 $\alpha$ and TXA-2 (measured as TXB-2), together with PGE-2. PGD-2 was not measured due to the lack of an RIA for this substance, but previous studies have shown PGD-2 synthesis by the rat uterus to be greater than PGE-2 synthesis but less than PGF- $2 \alpha$ synthesis (Poyser \& Scott, 1980). Text-figure 1 shows the changes which occurred in uterine PG and TX synthesizing ability at 4-h intervals during the 4-day cycle. Peak production of 6-oxo-PGF-1 $\alpha$, PGF$2 \alpha$, TXB-2 and PGE-2 occurred at $02: 00 \mathrm{~h}$ on the day of oestrus. Between $02: 00$ and $06: 00 \mathrm{~h}$ on the day of oestrus, 6-oxo-PGF- $1 \alpha$ production rapidly fell, rose again to a secondary peak at $14: 00 \mathrm{~h}$ on the day of oestrus, and then gradually fell, with some fluctuations on the day of metoestrus, to reach its minimum at $22: 00 \mathrm{~h}$ on the day of dioestrus. PGF-2 $\alpha$, PGE- 2 and TXB- 2 productions fell during the day of oestrus from their peak at $02: 00 \mathrm{~h}$, showed some fluctuations on the day of metoestrus in parallel with the changes in 6-oxo-PGF- $1 \alpha$ production, and reached a minimum at $06: 00 \mathrm{~h}$ on the day of pro-oestrus. PGF- $2 \alpha$ and 6-oxo-PGF- $1 \alpha$ productions showed a small increase on the morning of pro-oestrus although the amounts produced were not different from those produced on the day of metoestrus. Between $18: 00$ and $02: 00 \mathrm{~h}$ on the days of pro-oestrus and oestrus, respectively, the productions of 6-oxo-PGF-1 $\alpha$, PGF- $2 \alpha$, TXB-2 and PGE-2 significantly $(P<0.05)$ increased $1 \cdot 5-, 2 \cdot 0-, 3 \cdot 9 \cdot$ and $1 \cdot 7$-fold, respectively.

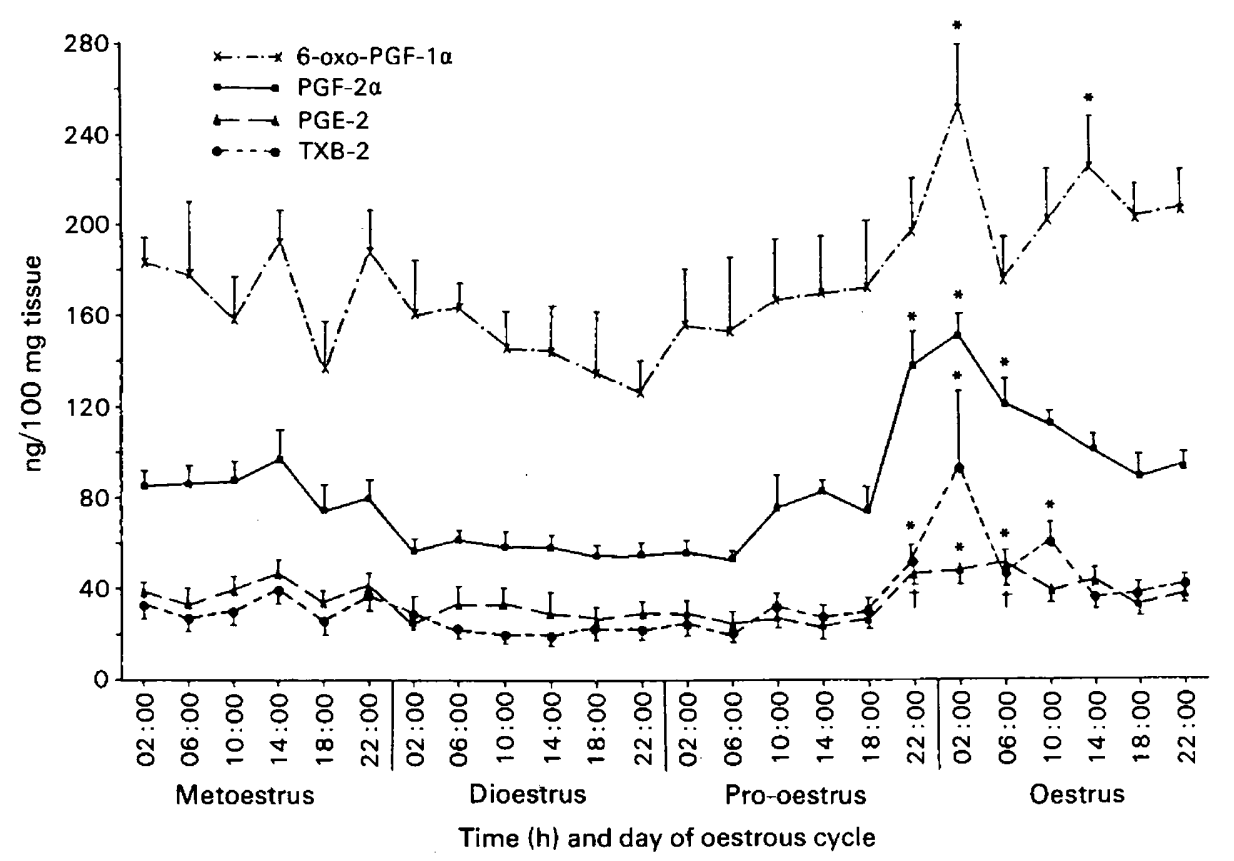

Text-fig. 1. Mean ( \pm s.e.m., $n=6$ ) production of prostaglandin (PG) E-2, PGF-2 $\alpha, 6$-oxoPGF- $1 \alpha$ and thromboxane (TX) B-2 by rat uterine homogenates at 4-h intervals throughout the 4-day oestrous cycle.

* For any one particular compound, values significantly higher than baseline values $(P<0.05)$. 


\section{Experiment 2}

At $02: 00 \mathrm{~h}$ on the day of oestrus, the uterine concentrations of 6-oxo-PGF-1 $\alpha$, PGF-2 $\alpha$ and TXB-2 were significantly higher $(P<0 \cdot 05), 3 \cdot 7-, 1 \cdot 4-$ and 3.2-fold, respectively, than at 10:00 h on the day of pro-oestrus. Uterine PGE-2 concentrations did not significantly change between these two times (Table 1). PGF-2 $\alpha$ was the major substance present at 10:00 h on the day of pro-oestrus while TXB-2 was the major substance present at $02: 00 \mathrm{~h}$ on the day of oestrus.

Table 1. Mean ( \pm s.e.m., $n=3$ ) concentrations (ng/100 mg tissue) of prostaglandin (PG) E-2, PGF-2 $\alpha$, 6-oxo-PGF- $1 \alpha$ and thromboxane (TX) B-2 in rat uterus

\begin{tabular}{lllll}
\hline \multicolumn{1}{c}{ Time } & PGE-2 & PGF-2 $\alpha$ & 6-oxo-PGF-1 $\alpha$ & TXB-2 \\
\hline $10: 00$ h on pro-oestrus & $1.40 \pm 0.30$ & $1.69 \pm 0.10$ & $0.72 \pm 0.07$ & $1.02 \pm 0.08$ \\
$02: 00$ h on oestrus & $1.00 \pm 0.08$ & $2.32 \pm 0.30^{*}$ & $2.66 \pm 0.39^{*}$ & $3.25 \pm 0.90^{*}$ \\
\hline
\end{tabular}

* Significantly $(P<0.05)$ higher than corresponding value at 10:00 h on the day of pro-oestrus.

\section{Experiment 3}

The amounts (ng/100 mg tissue; mean \pm s.e.m.) of 6-oxo-PGF-1 $\alpha$, PGF- $2 \alpha$, TXB-2 and PGE-2 produced by uterine homogenates at $10: 00 \mathrm{~h}$ on the day of pro-oestrus were, respectively, $249.0 \pm$ $42 \cdot 0,64 \cdot 0 \pm 10 \cdot 9,59 \cdot 8 \pm 29 \cdot 0$ and $32 \cdot 4 \pm 11 \cdot 3$ in the presence of exogenous arachidonic acid $(2$ $\mu \mathrm{g} / \mathrm{ml} ; n=4)$ and $167 \cdot 0 \pm 27 \cdot 0,76 \cdot 0 \pm 14 \cdot 4,31 \cdot 8 \pm 7 \cdot 2$ and $28.8 \pm 2.4$ in the absence of exogenous arachidonic acid $(n=6)$. The addition of exogenous arachidonic acid had no significant effect on uterine PG and TX production.

\section{Experiment 4}

The uterus metabolized $\left[{ }^{3} \mathrm{H}\right] \mathrm{PGF}-2 \alpha$ and $\left[{ }^{3} \mathrm{H}\right] \mathrm{PGE}-2$ into a mixture of the corresponding $15-$ keto and 13,14-dihydro-15-keto metabolites. In the absence of $\mathrm{NAD}^{+}$, total metabolism was low, although PGE-2 and PGF-2 $\alpha$ metabolism significantly $(P<0.05)$ increased and decreased, respectively, between $10: 00$ and $02: 00 \mathrm{~h}$ on the days of pro-oestrus and oestrus, respectively. The addition of NAD ${ }^{+}$significantly $(P<0.05)$ increased PGE-2 and PGF-2 $\alpha$ metabolism, except for PGF$2 \alpha$ metabolism at 10:00 $\mathrm{h}$ on the day of pro-oestrus (Table 2).

Table 2. Mean ( \pm s.e.m., $n=4)$ percentage metabolism of PGE-2 and PGF-2 $\alpha$ by rat uterine homogenates

\begin{tabular}{|c|c|c|c|c|}
\hline \multirow[b]{3}{*}{ Time } & \multicolumn{4}{|c|}{$\%$ metabolism } \\
\hline & \multicolumn{2}{|c|}{ PGE-2 } & \multicolumn{2}{|c|}{ PGF- $2 \alpha$} \\
\hline & Without NAD ${ }^{+}$ & With NAD ${ }^{+}$ & Without $\mathrm{NAD}^{+}$ & With NAD ${ }^{+}$ \\
\hline $\begin{array}{l}10: 00 \mathrm{~h} \text { on pro-oestrus } \\
02: 00 \mathrm{~h} \text { on oestrus }\end{array}$ & $\begin{aligned} 6 \cdot 7 & \pm 0 \cdot 2 \\
16.5 & \pm 3 \cdot 5^{*}\end{aligned}$ & $\begin{array}{c}26.6 \pm 10.2 \dagger \\
30.2 \pm 5.6 \dagger\end{array}$ & $\begin{aligned} 11.8 & \pm 3.4 \\
4.7 & \pm 1.2^{*}\end{aligned}$ & $\begin{array}{l}11.9 \pm 3.6 \\
12.8 \pm 4.2 \dagger\end{array}$ \\
\hline
\end{tabular}

* Significantly $(P<0.05)$ different from corresponding value at 10:00 h on pro-oestrus.

+ Significantly $(P<0.05)$ higher than corresponding value without $\mathrm{NAD}^{+}$. 


\section{Experiment 5}

PGF- $2 \alpha$ and 6-oxo-PGF-1 $\alpha$ were the major PGs synthesized by the endometrium and myometrium, respectively (Table 3 ). Expressed on a total weight basis, the myometrium produced 1.3- to 1.6-fold more PGs and TX than did the endometrium. However, expressed on a unit weight basis, PG and TX production by the endometrium was 10 - to 30 -fold higher than by the myometrium. The endometrial productions (ng/100 mg tissue) of PGF-2 $\alpha$, TXB-2 and 6-oxo-PGF-1 $\alpha$ significantly $(P<0.05)$ increased 5.6-, 3.6- and $2 \cdot 5$-fold, respectively, between $10: 00$ and $02: 00 \mathrm{~h}$ on

Table 3. Mean ( \pm s.e.m.) amounts of prostaglandin (PG) E-2, PGF- $2 \alpha, 6$-oxo-PGF-1 $\alpha$ and thromboxane (TX) B-2 produced by homogenates of rat endometrium and myometrium at 10:00 h on pro-oestrus $(n=$ 6) and 02:00 h on oestrus $(n=7)$

\begin{tabular}{|c|c|c|c|c|}
\hline Tissue and time & PGE-2 & PGF-2 $\alpha$ & 6-oxo-PGF-1 $\alpha$ & TXB-2 \\
\hline & \multicolumn{4}{|c|}{ ng total } \\
\hline $\begin{array}{l}\text { Endometrium } \\
10: 00 \mathrm{~h} \text { on pro-oestrus } \\
02: 00 \mathrm{~h} \text { on oestrus }\end{array}$ & $\begin{array}{l}39 \cdot 3 \pm 8 \cdot 4 \\
32 \cdot 4 \pm 3 \cdot 1\end{array}$ & $\begin{array}{l}141.0 \pm 24.5 \\
316.0 \pm 48.6^{*}\end{array}$ & $\begin{array}{l}29.7 \pm 5.6 \\
37.7 \pm 8.0\end{array}$ & $\begin{array}{l}43 \cdot 4 \pm 8 \cdot 4 \\
70.4 \pm 8 \cdot 5^{*}\end{array}$ \\
\hline $\begin{array}{l}\text { Myometrium } \\
\text { 10:00 h on pro-oestrus } \\
02: 00 \mathrm{~h} \text { on oestrus }\end{array}$ & $\begin{array}{l}77.2 \pm 11.8 \\
52.4 \pm 3.9^{*}\end{array}$ & $\begin{array}{c}92.8 \pm 37.9 \\
152.0 \pm 10.8^{*}\end{array}$ & $\begin{array}{l}185.0 \pm 18.5 \\
312.0 \pm 38.5^{*}\end{array}$ & $\begin{array}{l}56 \cdot 8 \pm 8 \cdot 1 \\
74 \cdot 6 \pm 8.4\end{array}$ \\
\hline & \multicolumn{4}{|c|}{$\mathrm{ng} / 100 \mathrm{mg}$ tissue } \\
\hline $\begin{array}{l}\text { Endometrium } \\
10: 00 \mathrm{~h} \text { on pro-oestrus } \\
02: 00 \mathrm{~h} \text { on oestrus }\end{array}$ & $\begin{array}{l}170.0 \pm 61.0 \\
291.0 \pm 45.0\end{array}$ & $\begin{array}{c}504 \cdot 0 \pm 127 \cdot 0 \\
2800 \cdot 0 \pm 749 \cdot 0^{*}\end{array}$ & $\begin{array}{l}126 \cdot 0 \pm 27 \cdot 0 \\
315 \cdot 0 \pm 49 \cdot 0^{*}\end{array}$ & $\begin{array}{l}183 \cdot 0 \pm 72 \cdot 0 \\
650.0 \pm 147 \cdot 0^{*}\end{array}$ \\
\hline $\begin{array}{l}\text { Myometrium } \\
10: 00 \mathrm{~h} \text { on pro-oestrus } \\
02: 00 \mathrm{~h} \text { on oestrus }\end{array}$ & $\begin{array}{l}18 \cdot 0 \pm 3 \cdot 1 \\
11 \cdot 1 \pm 1 \cdot 0^{*}\end{array}$ & $\begin{array}{l}24 \cdot 2 \pm 5 \cdot 0 \\
37 \cdot 3 \pm 3 \cdot 1^{*}\end{array}$ & $\begin{array}{l}45.0 \pm 5.8 \\
78.2 \pm 8.9^{*}\end{array}$ & $\begin{array}{l}16.0 \pm 1.9 \\
17.3 \pm 1.0\end{array}$ \\
\hline
\end{tabular}

* Significantly $(P<0.05)$ different from corresponding value at 10:00 h on pro-oestrus.

Table 4. Mean ( \pm s.e.m.) amounts of prostaglandin (PG) E-2, PGF-2 $\alpha$, 6-oxo-PGF-1 $\alpha$ and thromboxane (TX) B-2 produced by uterine homogenates from acutely ovariectomized rats (Group 1; 6 rats/subgroup) and long-term ovariectomized rats (Group 2;11 rats/subgroup) after no treatment (Control) or treatment with oestradiol and progesterone (Treated)

\begin{tabular}{|c|c|c|c|c|}
\hline Group & PGE-2 & PGF- $2 \alpha$ & 6-oxo-PGF-1 $\alpha$ & TXB-2 \\
\hline & \multicolumn{4}{|c|}{ ng total } \\
\hline $\begin{array}{l}\text { Group 1 } \\
\text { Control } \\
\text { Treated }\end{array}$ & $\begin{array}{l}101 \pm 24 \\
245 \pm 41^{*}\end{array}$ & $\begin{array}{l}131 \pm 17 \\
280 \pm 40^{*}\end{array}$ & $\begin{array}{l}571 \pm 114 \\
987 \pm 136^{*}\end{array}$ & $\begin{array}{l}185 \pm 19 \\
560 \pm 230^{*}\end{array}$ \\
\hline $\begin{array}{l}\text { Group } 2 \\
\text { Control } \\
\text { Treated }\end{array}$ & $\begin{array}{c}46 \pm 14 \\
187 \pm 29^{*}\end{array}$ & $\begin{array}{c}51 \pm 18 \\
208 \pm 21^{*}\end{array}$ & $\begin{array}{l}106 \pm 26 \\
376 \pm 33^{*}\end{array}$ & $\begin{array}{c}32 \pm 9 \\
183 \pm 33^{*}\end{array}$ \\
\hline & \multicolumn{4}{|c|}{$\mathrm{ng} / 100 \mathrm{mg}$ tissue } \\
\hline $\begin{array}{l}\text { Group 1 } \\
\text { Control } \\
\text { Treated }\end{array}$ & $\begin{array}{l}35 \pm 4 \\
46 \pm 10\end{array}$ & $\begin{array}{l}41 \pm 7 \\
61 \pm 7\end{array}$ & $\begin{array}{r}68 \pm 67 \\
178 \pm 33\end{array}$ & $\begin{array}{l}56 \pm 5 \\
64 \pm 9\end{array}$ \\
\hline $\begin{array}{l}\text { Group } 2 \\
\text { Control } \\
\text { Treated }\end{array}$ & $\begin{array}{l}72 \pm 10 \\
86 \pm 8\end{array}$ & $\begin{array}{c}66 \pm 7 \\
106 \pm 10^{*}\end{array}$ & $\begin{array}{l}140 \pm 15 \\
170 \pm 12\end{array}$ & $\begin{array}{l}48 \pm 6 \\
75 \pm 11^{*}\end{array}$ \\
\hline
\end{tabular}

* Significantly $(P<0.05)$ higher than corresponding control value. 
the days of pro-oestrus and oestrus, respectively. Endometrial PGE-2 production increased 1-7-fold between these two times, but the difference was not significantly different. The myometrial production (ng/100 mg tissue) of PGF- $2 \alpha$ and 6-oxo-PGF-1 $\alpha$ significantly $(P<0.05)$ increased 1.5 and $1 \cdot 7$-fold, respectively, while the myometrial productions of PGE-2 significantly $(P<0 \cdot 05)$ decreased by $38 \%$ and of TXB- 2 showed no change, between the two times studied.

\section{Experiment 6}

The treatment of acutely (Group 1) and long-term (Group 2) ovariectomized rats with oestradiol and progesterone significantly $(P<0.05)$ increased uterine PG and TX productions, when expressed on a total weight basis. However, when the results are expressed on a unit weight basis, only PGF- $2 \alpha$ and TXB-2 productions were significantly $(P<0.05)$ increased in the long-term (Group 2$)$ ovariectomized rats (Table 4).

\section{Discussion}

Rat uterine homogenates synthesized PGs and TX when incubated in vitro. Since (i) tissue concentrations of PGs and TX were low, (ii) arachidonic acid availability was not limiting PG and TX production by uterine homogenates, and (iii) metabolism of PGs by uterine homogenates in the absence of NAD ${ }^{+}$was low, the amounts of PGs and TX produced are indicative of the PG and TX synthesizing ability of the uterus. Changes in this PG and TX synthesizing ability occurred during the 4-day cycle, with its nadir being reached between $22: 00$ and $06: 00 \mathrm{~h}$ on the days of dioestrus and pro-oestrus respectively, and its peak being reached at $02: 00 \mathrm{~h}$ on the day of oestrus. Smaller 'peaks' were apparent at 10:00 h on the day of oestrus (6-oxo-PGF-1 $\alpha$ only), and at $14: 00$ and $22: 00 \mathrm{~h}$ on the day of metoestrus. The changes were probably due to changes in the amount of PGH-2 synthetase present in the uterus, since the production of one compound did not occur at the expense of another. This is contrary to the findings of Ham et al. (1975) who found PGF- $2 \alpha$ production to increase at the expense of PGE-2 production.

The peak production of PGs and TX by the rat uterus at $02: 00 \mathrm{~h}$ coincides exactly with the peak production of PGs and TX by the rat ovary (Brown \& Poyser, 1984a). This suggests that the hormonal control of PG production by the uterus has a time course similar to that which controls PG production by the ovary for which luteinizing hormone (LH), released in response to oestradiol and progesterone, is the final stimulus (Bauminger \& Lindner, 1975). Consequently, acutely and longterm ovariectomized rats were treated with oestradiol and progesterone in dose regimens that elicit LH release and thus mimic the effects of these steroids on the day of pro-oestrus (Caligaris, Astrada \& Taleisnik, 1968; Kalra, Fawcett, Krulich \& McCann, 1973). However, oestradiol and progesterone treatment caused only a small, but significant, increase in PGF- $2 \alpha$ and TXB-2 productions, but not in PGE-2 and 6-oxo-PGF-1 $\alpha$ productions, by the uterus from long-term ovariectomized rats (on a unit weight basis). This is again contrary to the findings of Ham et al. (1975) who reported that oestradiol treatment of ovariectomized rats stimulated uterine PGF- $2 \alpha$ production at the expense of PGE-2 production. Oestradiol treatment of ovariectomized rats has been reported to decrease PGF- $2 \alpha$ and PGF-2 productions by uterine homogenates (Thaler-Dao, Ramonatxo, Saintot, Chantreuil \& Crastes de Paulet, 1982b). Varied effects of ovarian steroid hormones on the uterine PG-synthesizing ability of ovariectomized rats have therefore been obtained, although some of the discrepancies may be attributable to differences in experimental design. Nevertheless, it would appear that oestradiol and progesterone alone cannot account for the increase in uterine PG and TX synthesizing ability between $18: 00$ and $02: 00 \mathrm{~h}$ on the days of pro-oestrus and oestrus, respectively, which suggests that other hormones are involved.

It is also clear that the increase in PG synthetase activity between 10:00 and $02: 00 \mathrm{~h}$ on the days of pro-oestrus and oestrus, respectively, occurs to a much greater extent in the endometrium 
than in the myometrium. Also, the different PGs and TX are not affected to the same extent, with endometrial TXB-2 and PGF-2 $\alpha$ productions showing the greatest increases. The total amount of PGs and TX synthesized by the endometrium and myometrium when incubated separately was approximately $60 \%$ less than when whole uterine homogenates were used, at $02: 00 \mathrm{~h}$ on the day of oestrus. This finding agrees with the similar results obtained by Abel \& Kelly (1979) for human uterine tissues, and supports their view that, in whole uterine homogenates, PGH-2 synthesized by endometrial PGH-2 synthetase is converted into the primary PGs (particularly 6-oxo-PGF-1 $\alpha$ ) by the appropriate enzymes present in the myometrium. However, the results of Campos, Liggins \& Seamark (1980), who measured PG output from the rat endometrium and myometrium superfused from the intact uterus in vitro, do not support the suggestion of Abel \& Kelly (1979) that PGH-2 synthesized by the endometrium is converted into primary PGs by the myometrium in the uterus in vivo. Nevertheless, this does not rule out the possibility that primary PGs and TXA-2 synthesized by the endometrium will act on the myometrium.

All the primary PGs and TXA-2 contract the pregnant rat uterus (Phillips \& Poyser, 1981; Dubin, Blake, Egner \& Ghodgaonkar, 1982). The output of TXA-2 from the pregnant, contracting rat uterus at term in vitro is greater than the outputs of PGF-2 $\alpha$, PGE-2 and PGI-2, and it is exceeded only by the output of the comparatively inactive PGD-2 (Phillips \& Poyser, 1981). TXA-2 is produced by the rat uterine tissues and not by the platelets trapped in the uterine blood vessels (Dubin, Ghodgaonkar \& Blake, 1983). Little is known about the motility of the rat uterus around the time of ovulation, although sperm transport into the oviduct is most rapid around the time of ovulation (i.e. $02: 00 \mathrm{~h}$ on the day of oestrus), suggesting that some uterine factor is involved (Shalgi \& Kraicer, 1978). Increased endometrial TXA-2 and PGF- $2 \alpha$ synthesis may therefore increase uterine contractility at that time. Increased $P G I-2$ production may potentiate such spasmogenic actions of TXA-2 and PGF-2 $\alpha$ (Williams, El Tahir \& Marcinkiewicz, 1979). In addition, gap junction formation, which is considered essential for synchronous uterine contractions (Garfield, Sims, Kannan \& Daniel, 1978) is inhibited by indomethacin, and is restored by 11,9-epoxymethanoPGH-2 (a TXA-2 mimic) but not by PGE-1, PGE-2, PGF-2 $\alpha$ or TXB-2 (Garfield, Kannan \& Daniel, 1980). This finding suggests that TXA-2 production by the uterus has a prime role in increasing uterine contractility. The effect of a TXA-2 synthesis inhibitor or TXA-2 receptor antagonist on uterine contractions and fertility of rats merits investigation. In this context, EP 092 (a thromboxane receptor antagonist) suppresses the oestradiol-induced increase in uterine wet and dry weights and potentiates the oestradiol-induced increase in uterine blood flow in rats, suggesting that TXA-2 is involved in the uterotrophic effect of oestradiol but, due to its vasoconstrictor action, attenuates the increase in blood flow in response to oestradiol (Senior \& Troughton, 1984).

This study was supported by a grant from the M.R.C., and a postgraduate research studentship to C.G.B. Authentic PGs and TXB-2 were kindly supplied by the Upjohn Co., Kalamazoo, Michigan, U.S.A. The demonstration of the technique for separating rat uterine tissues by Dr I. Downing was much appreciated.

\section{References}

Abel, M.H. \& Kelly, R.W. (1979) Differential production of prostaglandins within the human uterus. Prostaglandins 5, 821-828.

Bauminger, S. \& Lindner, H.R. (1975) Periovulatory changes in ovarian prostaglandin formation and their hormonal control in the rat. Prostaglandins 9, 737751.

Brown, C.G. \& Poyser, N.L. (1984a) Studies on ovarian prostaglandin production in relation to ovulation in the rat. J. Reprod. Fert. 72, 407-414.

Brown, C.G. \& Poyser, N.L. (1984b) Studies on the control of prostaglandin production by the hypothalamus in relation to $\mathbf{L H}$ release in the rat. $J$. Endocr. 103, 155-164.
Caligaris, L., Astrada, J.J. \& Taleisnik, S. (1968) Stimulating and inhibiting effects of progesterone on the release of luteinizing hormone. Acta endocr., Copenh. 59, 177-185.

Campos, G.A., Liggins, G.C. \& Seamark, R.F. (1980) Differential production of PGF and 6-keto-PGF ${ }_{1 \alpha}$.by the rat endometrium and myometrium in response to oxytocin, catecholamines and calcium ionophore. Prostaglandins 20, 297-310.

Dighe, K.K., Emslie, H.A., Henderson, L.K., Rutherford, F. \& Simon, L. (1975) The development of antisera to prostaglandins $B_{2}$ and $F_{2 \alpha}$ and their analysis using solid phase and double antibody radioimmunoassay

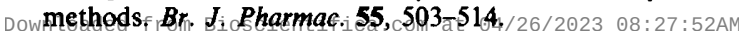


Downing, I. \& Williams, K.I. (1980) A comparison of arachidonic acid metabolism by microsomes from pregnant rat decidua and myometrium. Archs Int. Pharmacodyn. Ther. 247, 4-20.

Dubin, N.H., Blake, D.A., Egner, P.G. \& Ghodgaonkar, R.B. (1982) Effect of platelet generated thromboxane on contractions of the pregnant rat uterus. Biol. Reprod. 26, 289-295.

Dubin, N.H., Ghodgaonkar, R.B. \& Blake, D.A. (1983) Thromboxane production in the pregnant rat: differential recovery by platelets and uterus following aspirin administration. Biol. Reprod. 29, 743-750.

Garfield, R.E., Sims, S., Kannan, M.S. \& Daniel, E.E. (1978) The possible role of gap junctions in activation of the myometrium during parturition. $A m$. J. Physiol. 235, C168-C179.

Garfield, R.E., Kannan, M.S. \& Daniel, E.E. (1980) Gap junction formation in myometrium: control by estrogens, progesterone and prostaglandins. $\mathrm{Am} . J$. Physiol. 238, C81-C89.

Ham, E.A., Cirillo, V.J., Zanetti, M.E. \& Kuehl, F.A., Jr (1975) Estrogen-directed synthesis of specific prostaglandins in uterus. Proc. natn. Acad. Sci. U.S.A. 72, 1420-1424.

Ishikawa, M. \& Fuchs, A.-R. (1978) Effect of epinephrine and oxytocin on release of prostaglandin $F$ from the rat uterus in vitro. Prostaglandins 15, 89-102.

Kalra, P.S., Fawcett, C.P., Krulich, L. \& McCann, S.M. (1973) The effects of gonadal steroids on plasma gonadotropins and prolactin in the rat. Endocrinology 92, 1256-1268.

Lytton, F.D.C. \& Poyser, N.L. (1982) Concentrations of PGF- $2 \alpha$ and PGE-2 in the uterine venous blood of rabbits during pseudopregnancy and pregnancy. $J$. Reprod. Fert. 64, 421-429.

Mitchell, S., Poyser, N.L. \& Wilson, N.H. (1977) Effect of p-bromophenacyl bromide, an inhibitor of phospholipase $A_{2}$, on arachidonic acid release and prostaglandin synthesis by the guinea-pig uterus in vitro. Br. J. Pharmac. 59, 107-113.

Phillips, C.A. \& Poyser, N.L. (1981) Prostaglandins, thromboxanes and the pregnant rat uterus at term. Br. J. Pharmac. 73, 75-80.

Poyser, N.L. (1980) Development and use of a radio- immunoassay for measuring 6-oxo-prostaglandin $\mathrm{F}_{1 \alpha}$. In Prostaglandins, Prostacyclin and Thromboxanes Measurement, pp. 44-55. Eds J. M. Boeynaems \& A. G. Herman. Martinus Nijhoff, The Hague.

Poyser, N.L. (1983) Differential stimulation of prostaglandin and thromboxane synthesizing capacities in guinea-pig uterus and ovary. Prostaglandins, Leuk. \& Med. 10, 167-177.

Poyser, N.L. \& Scott, F.M. (1980) Prostaglandin and thromboxane production by the rat uterus and ovary in vitro during the oestrous cycle. J. Reprod. Fert. 60, $33-40$.

Saksena, S.K., Shaikh, S.A. \& Shaikh, A.A. (1973) Uterine and peripheral plasma F-prostaglandins correlated with peripheral progesterone in cyclic rats. Prostaglandins 4, 243-249.

Senior, J. \& Troughton, K.M. (1984) Modification of uterine responses to oestrogen in the rat by thromboxane receptor antagonist. $B r . J$. Pharmac. 81, 73P, Abstr.

Shalgi, R. \& Kraicer, P.F. (1978) Timing of sperm transport, sperm penetration and cleavage in the rat. J. exp. Zool. 204, 353-360.

Swan, C.G. \& Poyser, N.L. (1983) Prostaglandin synthesis by, and the effects of prostaglandins and prostaglandin analogues on, the vas deferens of the rabbit and rat in vitro. J. Reprod. Fert. 69, 91-99.

Thaler-Dao, H., Saintot, M., Ramonatxo, M., Chavis, C. \& Crastes de Paulet, A. (1982a) Prostaglandin biosynthesis by the rat uterus during the oestrous cycle. Temporal correlation with plasma oestradiol and progesterone. Prostaglandins 23, 347-360.

Thaler-Dao, H., Ramonatxo, M., Saintot, M., Chantreuil, J. \& Crastes de Paulet, A. (1982b) Effect of oestradiol $17 \beta$ on prostaglandin biosynthesis by the uterus of ovariectomized rat and guinea pig. Prostaglandins 24, 149-163.

Van Orden, D.E., Goodale, D.B., Baker, H.A., Farley, D.B. \& Bhatnagar, R.K. (1980) Uterine catecholamines and prostaglandins during the estrous cycle of the rat. Endocrinology 106, 1650-1654.

Williams, K.I., El Tahir, K.E.H. \& Marcinkiewicz, E. (1979) Dual actions of prostacyclin $\left(\mathrm{PGI}_{2}\right)$ on the rat pregnant uterus. Prostaglandins 17, 667-672. 